\title{
EDITORIAL
}

\section{Professor Amos B Smith, III}

The Journal of Antibiotics (2016) 69, 190; doi:10.1038/ja.2016.31

Pstan rofessor Amos B Smith, III has hosted 60 Japanese postdocs since 1982, and it is the greatest honor, luck and pleasure for me to have been one of them. On behalf of all those Japanese postdocs, I would like to sincerely express our profound respect for his accomplishments during his long and highly successful research career, and gratitude for a great deal of support and encouragement that he has extended to us since our return to Japan.

We are extremely glad that Professor Smith has worked 'very hard' for 50 years from the start in 1966 at Backnell University to his current activities at the University of Pennsylvania (Penn). His invaluable contributions during his stellar career have accelerated scientific advancements in several fields.

Professor Smith's research interests encompass three diverse areas: natural product synthesis, bioorganic chemistry and materials science. To date, $>90$ architecturally complex natural products have been produced in his laboratory. In addition, he, in collaboration with Professor Ralph Hirschmann, achieved the design and synthesis of non-peptide peptidomimetics of neuropeptideic hormone/transmitters and protease enzyme inhibitors. And he also obtained haptens for the production of catalytic antibodies capable of peptide bond formation with Professor Stephen Benkovic (Penn State). At Monell, in collaboration with Professor Peter Jurs (Penn State), he pioneered the use of computerized pattern recognition techniques for the analysis of primate chemical communication.

We believe Professor Smith has, for many years, been the world's outstanding leader among the natural products organic synthetic chemists.

I had a great pleasure of working with Professor Smith from 1988 to 1990 at Penn. My project was the total syntheses of architecturally complex indole alkaloids, paspalicine and paspalinine. During my stay, Professor Smith gave me a lot of ideas, guidance, stimulation and encouragement. Furthermore, he is always a great supporter toward Japanese research. From 1990, as a Visiting Director at The Kitasato
Institute, Tokyo, Japan, Professor Smith provided a great deal of valuable insights, suggestions and leadership, as well as very warm friendship, especially through collaboration with Professor Satoshi Ōmura.

Not surprisingly, as a true and special friend of Japan, Professor Smith has received many Japanese Honors and Awards, such as the Kitasato Institute Microbial Chemistry Medal (1990), Honorary Membership—Pharmaceutical Society of Japan (1999), Honorary Member-the Kitasato Institute (1990), the Yamada Prize, the Japan Research Foundation for Optically Active Compounds, (2003) and the nation's Order of the Rising Sun, Gold Rays with Neck Ribbon (2004).

Professor Smith served on the Editorial Board of The Journal of Antibiotics from 1998 and he was appointed as Emeritus Editorial Board member this year.

In closing, my fellow postdocs and I are delighted to publish this special issue in The Journal of Antibiotics entitled 'Amos B Smith, III: 50 years of Research and Contributions - Featuring Outstanding Contributions to Complex Natural Product Total Synthesis, Bioorganic and Medicinal Chemistry', under the supervision of Editor-in-Chief, Professor Kuniaki Tatsuta and Section Editor, Dr Keiichi Ajito.

We really hope that Professor Smith will continue his world-leading research for many years to come, and that he will continue to play an active role in extending and deepening the ties between his laboratories, his work and his connections with us all in Japan, and we wish him the best of luck and greatest success in his future endeavors.
Toshiaki Sunazuka Kitasato Institute for Life Sciences and Graduate School of Infection Control Sciences, Kitasato University, Tokyo, Japan E-mail: sunazukatoshiaki@yahoo.co.jp 